\title{
THE PREVENTIVE EFFECTS OF RUTIN ON IMMOBILIZATION STRESS-INDUCED CARDIAC DAMAGE
}

\author{
RESIT COSKUN ${ }^{1}$, AZIZ INAN CELIK $^{2 *}$, ZEYNEP SULEYMAN $^{3}$, \\ FERDA KESKIN CIMEN ${ }^{4}$ and MURAT CANKAYA ${ }^{5}$
}

\author{
${ }^{1}$ Department of Cardiology, Faculty of Medicine, Erzincan Binali Yildirim University, Erzincan, Turkey \\ ${ }^{2}$ Department of Cardiology, Gebze Fatih State Hospital, Kocaeli, Turkey \\ ${ }^{3}$ Department of Nursing, Faculty of Health Sciences, Erzincan Binali Yildirim University, Erzincan, Turkey \\ ${ }^{4}$ Department of Pathology, Faculty of Medicine, Erzincan Binali Yildirim University, Erzincan, Turkey \\ ${ }^{5}$ Department of Biology, Faculty of Arts and Sciences, Erzincan Binali Yildirim University, Erzincan, \\ Turkey
}

\begin{abstract}
The previous studies formed the role of oxidants and proinflammatory cytokines in the pathogenesis of acute psychological stress-related cardiac damage leading to mortality and other complications. The aim of the study is to examine the protective effect of rutin against stress-induced cardiac damage. In the literature, no studies have been found analyzing the effects of rutin in acute stress-related oxidative damage induced by immobilization method in rats. Rutin was administered orally to rutin + stress applied (RSG) group albino rats at a dose of $50 \mathrm{mg} / \mathrm{kg}$. For healthy control (HG) and stress applied to control (SAG) groups, distilled water as a solvent was orally administered at the same volume $(0.5 \mathrm{~mL})$. One hour after rutin and distilled water applications, all animals except for HG brought into a supine position and their legs and arms were ligated and kept in the same position for $24 \mathrm{~h}$. The oxidant, cytokine and cardiac biomarker levels in blood serum and heart tissues of SAG animals were found to be significantly higher and total glutathione was lower than RSG and HG groups. Histopathologically dilated congested blood vessels and myocardial destruction, hemorrhage, edema, and polymorphonuclear leukocyte infiltration were observed in the SAG heart tissues. On the other hand, the histological heart tissue results of the RSG group was found to be similar compared to the healthy tissue except for the slightly dilated congested blood vessel. These results indicate that the rutin may be useful in the treatment of stress-related oxidative cardiac damage.
\end{abstract}

Keywords: rutin, immobilization, stress, myocardial damage

Previous studies have shown that psychosocial factors play an important role in the pathogenesis of coronary artery disease (CAD) and may increase mortality and morbidity in patients with CAD (1-3). Acute psychological stress has been shown to induce myocardial ischemia in different stress models in laboratories (4). In animals, the acute compulsory immobilization method (movement restriction) was used to generate the stress-induced myocardial injury model (5). The stress conditions faced by humans and animals lead to biochemical, structural and functional deterioration (6). Oxidant/antioxidant parameters were generally used in the determination of biochemical toxic effect (7). The restriction of movement evaluated by biochemical parameters was shown to cause oxidative stress in animals (8). Thus, assessing oxidant/antioxidant balance may reveal whether tis- sue damage occurred (9). The oxidant/antioxidant balance is maintained by continuously producing free oxygen radicals (ROS) and antioxidants in living tissues under strict control (10). If antioxidants fail to neutralize ROSs subsequently over-accumulated ROSs oxidize cell membrane lipids, resulting in the formation of cytotoxic products such as malondialdehyde (MDA) (9). Overproduction of ROSs enables to reveal excessive amounts of myeloperoxidase from a damaged cell and leads to the activation of polymorphic leukocytes (PNL) which act as an oxidant enzyme source, therefore further increases the production of ROSs (11). Furthermore increased oxidants have been shown to induce secretion of interleukin, TNF- $\alpha$ and other proinflammatory cytokines (12). Biochemical analyses have shown the role of proinflammatory cytokines such as tumor necrosis

$\bar{*}$ Corresponding author: e-mail: azizinanmd@hotmail.com 
factor-alpha (TNF- $\alpha$ ) and interleukin 1 beta (IL-1 $\beta$ ) in myocardial injury (13). The previous experimental study demonstrated the relevance of acute stress damage ranging from endothelial dysfunction to tissue necrosis (14). Recently, in the study of Koptev MM and et. al. has been reported that acute stress caused by immobilization method contributes to the occurrence of more than one lesion morphologically (5). In a study examining the tissue damage, the severity of biochemical toxic effect was found to be directly proportional to histopathologic damage severity (6). All these data showed that oxidant and proinflammatory factors play a significant role in the pathogenesis of stress-related cardiac damage. It has been suggested in the literature that drugs inhibiting oxidative and proinflammatory cytokine productions may be useful in the treatment and prophylaxis of stress-related cardiac damage (12). In our study, we will examine the protective effect of rutin $\left(3,3^{\prime}, 4^{\prime}, 5,7\right.$-pentahydroxyflavone-3-rhamnoglucoside) against stress-induced oxidative cardiac damage, which is a flavonoid P1 vitamin (15). Rutin has been shown to inhibit proinflammatory cytokine production and to produce an antioxidant effect. In addition, it maintains vascular barrier integrity and reduces hyperpermeability (16, 17). All the data obtained have suggested that the rutin may be useful in preventing the development of stress-related oxidative cardiac damage. In light of the current literature, no studies were found examining the effect of rutin on oxidative cardiac damage induced by immobilization stress method on rats. The aim of our study is to biochemically and histopathologically analyze the effect of rutin on immobilization induced acute stress-related oxidative cardiac damage in rats.

\section{MATERIAL AND METHODS}

\section{Animals}

A total of 18 albino Wistar male rats approximately 5-month-old and weighing 245-255 grams was obtained from Atatürk University Medical Experimental Application and Research Center. The rats housed at normal room temperature $\left(22^{\circ} \mathrm{C}\right)$. The animals had access to feeding and water without restriction all day and night prior to the experiment. The protocols and procedures approved by the local Animal Experimentation Ethics Committee. (Date: 26.10.2017, meeting no: 11).

\section{Chemicals}

Thiopental sodium used in the experiment was obtained from IE Ulagay (Turkey) and rutin was obtained from Solgar (USA).

\section{Experiment groups}

The rats used in our study were divided into healthy (HG), stress applied to control (SAG) and rutin + stress applied (RSG) groups.

\section{Experiment procedure}

Cardiac damage was performed using forced immobilization in rats. The rutin was administered to RSG $(n=6)$ group animals with a catheter directly to gastrum at a dose of $50 \mathrm{mg} / \mathrm{kg}$ for application of this experiment (12). For the HG $(n=6)$ and $\operatorname{SAG}(n=6)$ groups, distilled water as a solvent was applied at the same volume $(0.5 \mathrm{~mL})$ and with the same method. One hour after rutin and distilled water application, the rats (except for $\mathrm{HG}$ ) were brought into the supine position and their legs and arms were tied and they were kept in the same position for $24 \mathrm{~h}$. At the end of this period, blood samples were taken from the tail veins of all of the animals then were sacrificed by a high dose of anesthesia $(50 \mathrm{mg} / \mathrm{kg}$ thiopental sodium) and their hearts were removed. Malondialdehyde (MDA), myeloperoxidase (MPO), total glutathione (tGSH), IL-1 $\beta$ and TNF- $\alpha$ levels were measured in blood samples and heart tissues of the animals. Biochemical and histopathologic results obtained from HG and RSG groups were compared with SAG.

\section{Biochemical analyzes Preparation of the samples}

Blood samples were obtained from all rats and were collected into separation gel vacutainer serum tubes. All blood samples were incubated for $15 \mathrm{~min}$. at room temperature and then serum layers were separated by centrifugation at $1500 \mathrm{xg}$ for $15 \mathrm{~min}$. All serum samples were stored at $-80^{\circ} \mathrm{C}$ until the biochemical analysis was performed. Prior to dissection, heart tissue was rinsed with phosphatebuffered saline solution. The heart tissue was homogenized in ice-cold phosphate buffers $(50 \mathrm{mM}$, $\mathrm{pH} 7,4)$ being appropriate for the variables to be measured. The tissue homogenates were centrifuged at 5,000 rpm for $20 \mathrm{~min}$. at $4^{\circ} \mathrm{C}$, and the supernatants were extracted in order to analyze MDA, tGSH, MPO, IL-1 $\beta$, TNF $\alpha$, and protein concentration. The protein concentration of the supernatant was measured using the method described by Bradford MM. All tissue results were expressed by dividing them into $g$ protein (18).

\section{MDA levels in serum and tissue}

MDA measurements based on the method used by Ohkawa et al., involving spectrophotometrical measurement of absorbance of the pink-colored 
complex formed by thiobarbituric acid (TBA) and MDA The serum/tissue-homogenate sample $(0.1$ $\mathrm{mL}$ ) added to a solution containing $0.2 \mathrm{~mL}$ of $80 \mathrm{~g} / \mathrm{L}$ sodium dodecyl sulfate, $1.5 \mathrm{~mL}$ of $200 \mathrm{~g} / \mathrm{L}$ acetic acid, $1.5 \mathrm{~mL}$ of $8 \mathrm{~g} / \mathrm{L}$ 2-thiobarbiturate, and $0.3 \mathrm{~mL}$ distilled water. The mixture incubated at $95^{\circ} \mathrm{C}$ for $1 \mathrm{~h}$. Upon cooling, $5 \mathrm{~mL}$ of $\mathrm{n}$-butanol: pyridine $(15: 1)$ added. The mixture vortexed for $1 \mathrm{~min}$ and centrifuged for $30 \mathrm{~min}$ at $4000 \mathrm{rpm}$. The absorbance of the supernatant measured at $532 \mathrm{~nm}$. The Standard curve obtained by using 1,1,3,3tetramethoxypropane (19).

\section{MPO activity in serum and tissue}

According to the method defined by Bradly et al. To determine MPO activity in serum/tissuehomogenates, $\mathrm{H}_{2} \mathrm{O}_{2}$ involving in phosphate buffer (50 mM, pH 6) used as a substrate. Assay buffer prepared $(7.5 \mathrm{mg}$ o-dianisidine- $\mathrm{HCl}, 5 \mathrm{~mL} 0.0005 \%$ $\mathrm{H}_{2} \mathrm{O}_{2}$ in $40 \mathrm{~mL}$ phosphate buffer). $20 \mu \mathrm{L}$ serum/tissue-homogenate added $280 \mu \mathrm{L}$ assay buffer. The MPO activity was kinetically measurement at 460 $\mathrm{nm}$ for $5 \mathrm{~min}(20)$.

\section{tGSH analysis in serum and tissue}

According to the method defined by Sedlak $\mathrm{J}$ and Sedlak J, Lindsay RH. DTNB (5, 5'-dithiobis [2-nitrobenzoic acid]) disulfate is chromogenic in the medium, and DTNB is reduced easily by sulfhydryl groups. The yellow color produced during the reduction is measured by spectrophotometry at $412 \mathrm{~nm}$. For measurement, a cocktail solution (5.85 mL $100 \mathrm{mM}$ Na-phosphate buffer, $2.8 \mathrm{~mL}$ $1 \mathrm{mM}$ DTNB $3.75 \mathrm{~mL} 1 \mathrm{mM} \mathrm{NADPH}$, and $80 \mu \mathrm{L}$ $625 \mathrm{U} / \mathrm{L}$ Glutathione reductase was prepared. Before measurement, $0.1 \mathrm{~mL}$ meta-phosphoric acid added to $0.1 \mathrm{~mL}$ serum/tissue-homogenate and centrifuged for $2 \mathrm{~min}$ at $2000 \mathrm{rpm}$ for deproteinization. The $0.15 \mathrm{~mL}$ cocktail solution added to $50 \mu \mathrm{L}$ of the supernatant. The Standard curve obtained by using GSSG (21).

\section{IL-1 $\beta$ and TNF- $\alpha$ analysis in serum and tissue}

Serum and tissue-homogenate IL-1 $\beta$ and TNF- $\alpha$ concentrations were measured using ratspecific sandwich enzyme-linked immunosorbent assay Rat IL-1 $\beta$ ELISA Kit (Cat no: YHB0616Ra, Shanghai LZ) and Rat Tumor Necrosis Factor $\alpha$ ELISA kits (Cat no: YHB1098Ra, Shanghai LZ). Analyses performed according to the manufacturers' instructions. Briefly, a monoclonal antibody specific for rat IL- $1 \beta$ and TNF- $\alpha$ coated onto the wells of the microplates. The serum samples, standards and a biotinylated monoclonal antibody spe- cific and streptavidin-HRP were pipetted into these wells and then incubated at $37^{\circ} \mathrm{C}$ for $60 \mathrm{~min}$. After washing, chromogen reagent $\mathrm{A}$ and chromogen reagent $\mathrm{B}$ were added, which is acted upon by the bound enzyme to produce a color. It incubated at $37^{\circ} \mathrm{C}$ for $10 \mathrm{~min}$. Then stop solution was added. The intensity of this colored product is directly proportional to the concentration of rat IL- $1 \beta$ and TNF- $\alpha$ present in the original specimen. At the end of the course, the well plates read at $450 \mathrm{~nm}$ via a microplate reader (Bio-Tek, USA). The absorbance of the samples estimated with formulas that used standard graphics.

\section{Troponin I (TP I) assay}

Troponin I levels in the plasma obtained from animals were measured using the ELFA (EnzymeLinked Fluorescent Assay) technique in the VIDAS Troponin I Ultra kit. All the steps of the test using the ready-made test reagents were performed automatically on the VIDAS. The sample transferred to a well containing anti-cardiac troponin I antibodies labeled with alkaline phosphatase. The sample-conjugate mixture was withdrawn and released into the solid phase supplier to allow conjugation of troponin I and conjugate bound to the inner wall of the solid phase binder of the antigen. Unbound content removed by washing. The conjugate enzyme catalyzes the hydrolysis of 4-methylumbelliferone, a product measured at $450 \mathrm{~nm}$, of the substrate, 4methylumbelliferyl phosphate. The intensity of fluorescence is proportional to the concentration of antigen present in the sample.

\section{Histopathological examination}

Heart tissues obtained from the rats were fixed in $10 \%$ formalin solution for $24 \mathrm{~h}$. After routine tissue processing, 4 micron thick sections were obtained from the paraffin blocks and were stained with Hematoxylin \& Eosin. All sections were examined under the light microscope (Olympus BX 52, Tokyo, Japan) by two pathologists who do not know which treatment protocol is used.

\section{Statistical analysis}

Descriptive statistics generated for each group. The results obtained from the experiments expressed as "mean value \pm standard deviation" $(\mathrm{x} \pm \mathrm{SD})$. Outlier analysis was performed using the Tukey test. Differences between groups compared by one-way analysis of variance (ANOVA). All statistical analyses performed with "SPSS Statistics Version 18" statistical software and $\mathrm{p}$ values $<0.05$ were considered significant. 


\section{RESULTS}

MDA, MPO and tGSH quantitation results in blood serum and heart tissue

As can be seen in Figure 1, MDA and MPO levels in blood serum of SAG animals were found to be significantly higher $(\mathrm{p}<0.0001)$ and tGSH level was found to be lower ( $p<0.0001)$ than RSG and HG. MDA and MPO levels significantly increased $(p<0.0001)$ in the heart tissue of SAG compared to the RSG and HG, while tGSH decreased (Fig. 2). The difference between MDA, MPO and tGSH lev-

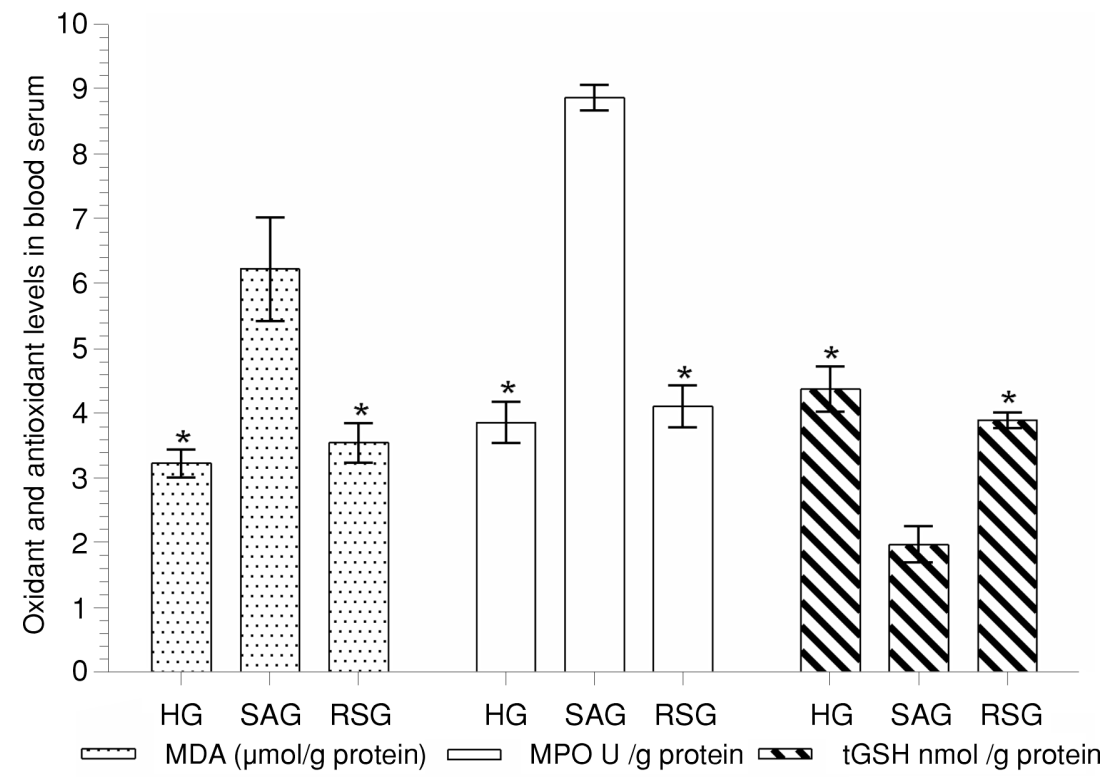

Figure 1. MDA, MPO and tGSH quantitation results in blood serum. RSG (Rutin + Stress Applied Group, $n=6$ ), SAG (Stress Applied Group, $\mathrm{n}=6$ ) and HG (Healthy Group, $\mathrm{n}=6)$. * $=\mathrm{p}<0.0001$ according to SAG group.

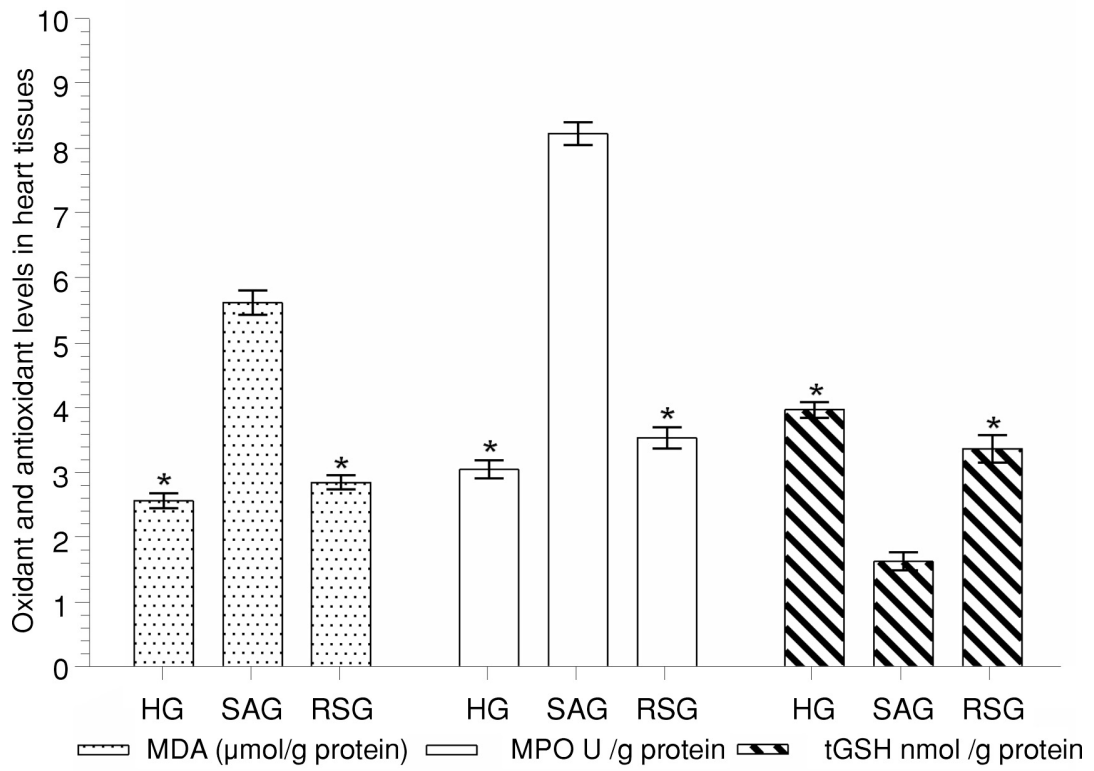

Figure 2. MDA, MPO and tGSH quantitation results in Heart tissue. RSG (Rutin + Stress Applied Group, $n=6$ ), SAG (Stress Applied Group, $\mathrm{n}=6$ ) and HG (Healthy Group, $\mathrm{n}=6$ ), ${ }^{*}=\mathrm{p}<0.0001$ according to SAG group. 


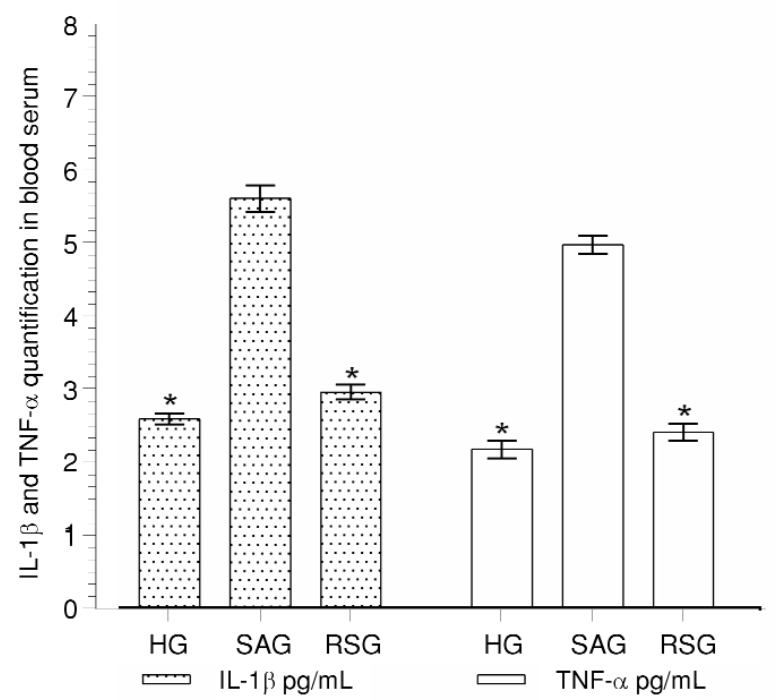

Figure 3. IL-1 $\beta$ and TNF- $\alpha$ quantification in blood serum. RSG (Rutin + Stress Applied Group, $n=6$ ), SAG (Stress Applied Group, $n=$ 6) and HG (Healthy Group, $n=6$ ). ${ }^{*}=p<0.0001$ according to SAG group.

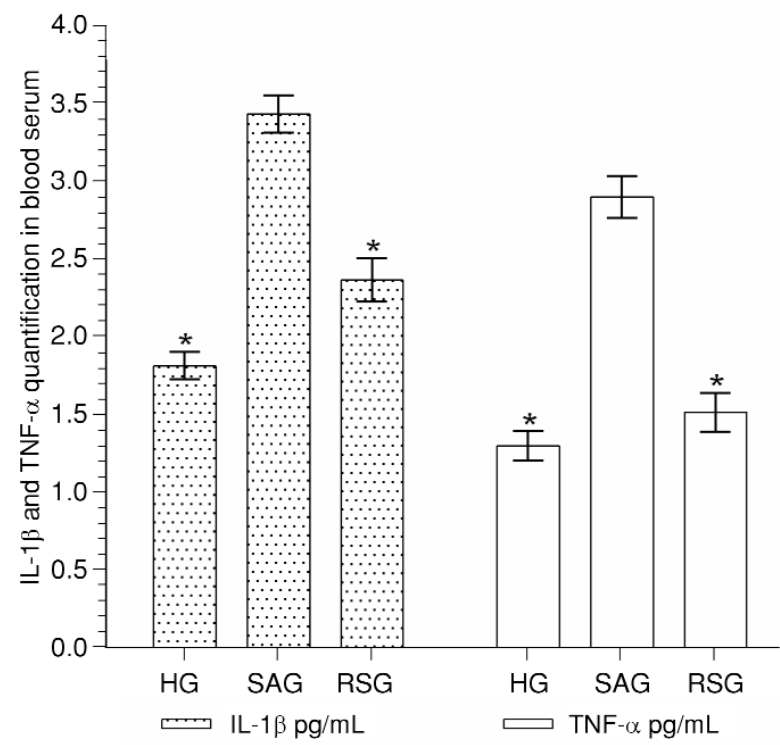

Figure 4. IL-1 $\beta$ and TNF- $\alpha$ quantification in Heart Tissue. RSG (Rutin + Stress Applied Group, $n=6$ ), SAG (Stress Applied Group, $n=$ 6) and HG (Healthy Group, $n=6$ ). ${ }^{*}=\mathrm{p}<0.0001$ according to SAG group.

els in the blood serum and heart tissue of the RSG and the MDA, MPO and tGSH levels in the HG were found to be statistically insignificant.

\section{Results of IL-1 $\beta$ and TNF- $\alpha$ quantification in blood serum and heart tissue}

Acute stress-induced immobilization method significantly increased IL- $1 \beta$ and TNF- $\alpha$ levels in animal blood serum ( $\mathrm{p}<0.0001)$ compared to RSG and HG (Fig. 3). In addition, this stress model caused to increase in IL- $1 \beta$ and TNF- $\alpha$ levels in the heart tissue (Figure 4). The difference between the amounts of IL-1 $\beta$ and TNF- $\alpha$ in the blood serum and heart tissues of the RSG and HG was found to be statistically insignificant $(p>0.05)$ (Fig. 3). 


\section{Blood serum TP I assay results}

The acute stress event induced by immobilization increased the blood serum TP I level of the SAG significantly $(\mathrm{p}<0.0001)$ compared to the RSG and HG (Fig. 5). The difference in TP I level between the RSG and the HG was found to be statistically insignificant $(\mathrm{p}>0.05)$.

\section{Histopathological results}

Normal histological structures of the epicardium, blood vessel, myocardium, and endocardium observed under microscopic examination of the heart tissue of HG were shown in Figure 6A. dilated congested blood vessel and cardiac muscle destruction were observed in the heart tissue of SAG (Fig. 6B).

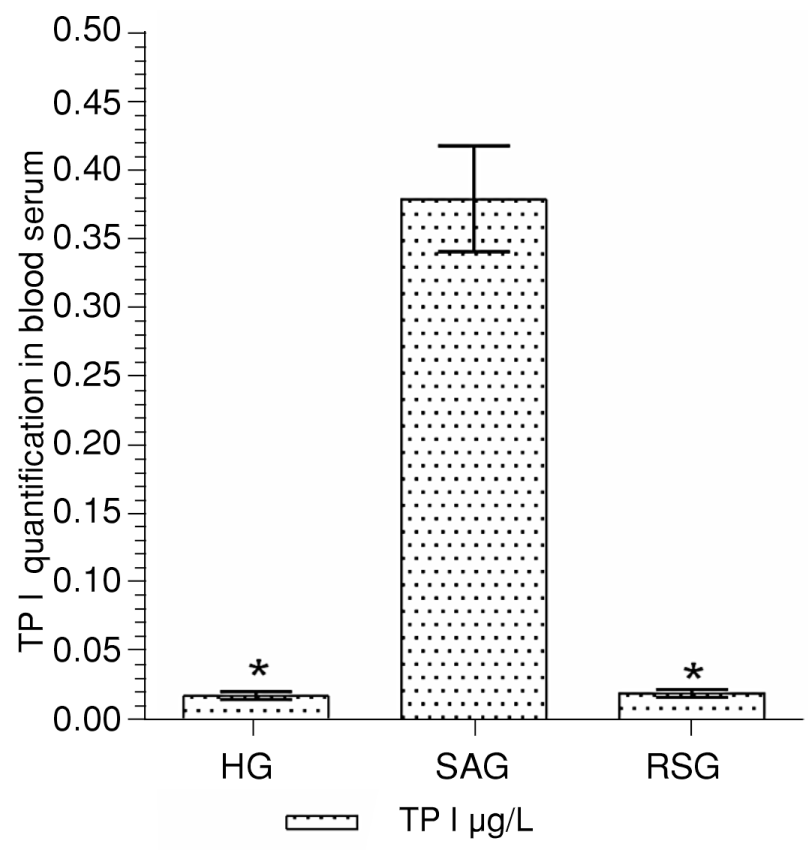

Figure 5. TP I Quantification in Blood serum. RSG (Rutin + Stress Applied Group, n = 6), SAG (Stress Applied Group, n = 6) and HG (Healthy Group, $\mathrm{n}=6$ ). ${ }^{*}=\mathrm{p}<0.0001$ according to SAG group.

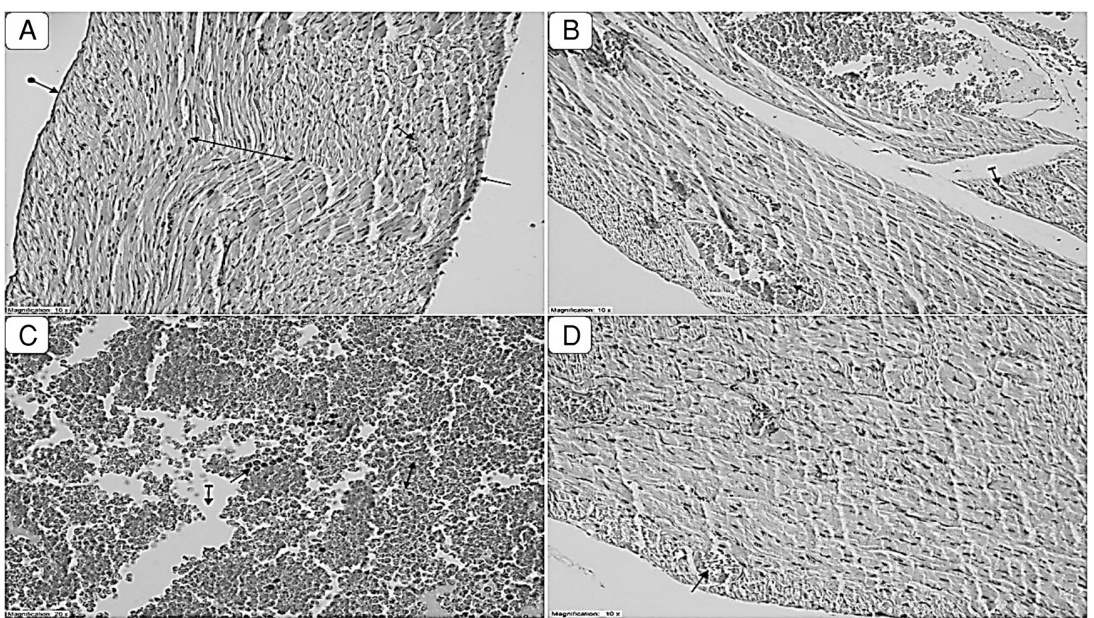

Figure 6. (A) Cardiac tissue of HG followed by normal healthy epicardium (straight arrow), blood vessel (striped arrow), myocardial (twosided arrow) and endocardial (round arrow) (HEX200). (B) In stress applied SAG heart tissue, dilated congested blood vessel (straight arrow) and destruction at heart muscle (striped arrow) are shown (HEX200). (C) Hemorrhage (two-sided arrow), edema (striped arrow) and polymorphic nuclear leucocyte infiltration (straight arrow) detected in the heart tissue of the SAG group applied with stress (HEX400). (D) Rutin+ stressed RSG group animals observed dilated congested blood vessel (arrow) and near-normal appearance (HEX200). 
Moreover, marked hemorrhage, edema and PNL infiltration in the heart tissue were found in this group (Fig. 6C). It was found that there was no histopathological evidence other than a slightly dilated congested blood vessels in the heart tissue of RSG animals (Fig. 6D).

\section{DISCUSSION}

The study was conducted to evaluate the effect of rutin on acute oxidative cardiac damage associated with acute stress induced by immobilization in rats biochemically and histopathologically. Biochemical test results showed that the immobilization method changed oxidant/antioxidant balance in the blood serum and heart tissue of the acutely stressed animals in favor of oxidants. As is known, the oxidant/antioxidant balance is maintained at the supremacy of antioxidants under physiological conditions (22). The deterioration of this balance by aggressive factors in favor of oxidants leads to tissue damage called oxidative stress (9). As can be understood from our experimental results, there was a significant increase in MDA and MPO levels in the blood serum and heart tissue of animals subjected to acute stress. It has been stated in the literature that MDA and MPO are oxidant determiners used to evaluate oxidative tissue damage (9). Similarly, the study results of Cakir OK and his colleagues are consistent with our experimental results. It has shown that psychological stress increases tissue MDA and MPO levels (23). MDA, the end product of lipid peroxidation, and MPO, an inflammatory determiner have been noted to increase in different psychological stress models (24). ROSs cause oxidative stress in cell membrane lipids, resulting in the formation of cytotoxic products such as MDA (26).

Another parameter showing the oxidant/antioxidant balance changed in favor of oxidants was tGSH. tGSH is an endogenous antioxidant molecule protecting biological membranes against lipid peroxidation in cells (28). Excessive production of free radicals surpasses the detoxifying capacity of tGSH and leads to a decrease in tGSH levels causing damage in the heart tissue (20). In SAG rats, tGSH levels were significantly lower compared to the level in RSG. Zaidi SK et al. also reported that the blood tGSH level of animals subjected to oxidative stress induced by the immobilization method decreased (29). Samarghandian S et al. have shown that the immobilization method causes oxidative stress in non-cardiac tissues (30). These supportive data from the literature and our experimental results have suggested that the immobilization method causes oxida- tive stress in the heart and blood serum animals. Our study also showed a significant increase in IL-1 $\beta$ and TNF- $\alpha$ levels in blood and heart tissue of immobilized animals. In the literature, several pro-inflammatory cytokines were found to be responsible for cardiac damage; particularly IL- $1 \beta$ and TNF- $\alpha$ have been reported to be secreted in response to ischemic myocardium. On the other hand, it was not observed in normal myocardium (13). No studies associating fully immobilization stress-related oxidative heart damage with proinflammatory cytokines such as IL$1 \beta$ and TNF- $\alpha$ have been found. However, studies have shown that IL- $1 \beta$ and TNF- $\alpha$ levels are increased in oxidative cardiac damage due to the use of toxic drugs (31). The data obtained from the literature confirms that the production of proinflammatory cytokines in the blood and heart tissue of immobilized animals may be increased due to oxidative stress. In addition to the high levels of oxidants and cytokines, increased levels of TP I in blood serum were suggestive for the presence of cardiac damage. TP I being a very sensitive parameter in myocardial injury is used in the diagnosis of myocardial infarction (32). It has been noted that as well as cytokine and oxidant parameters TP I increase in experimental oxidative cardiac damage $(31,33)$. Previous studies have suggested that the elevation of TP I might be due to damage in the myocardial membrane caused by reactive oxygen products (34). Scientific researches have shown that cardiac TP I correlates with oxidative stress, inflammation, and histopathologic severity (29).

According to the data in the literature, the rutin has an antioxidant effect, inhibits pro-inflammatory cytokine productions and maintains vascular barrier integrity $(16,17)$. The literature data were in consistency with the results of the study. MDA and MPO levels of the RSG were almost the same as the HG and showing the marked protective effect of rutin against oxidative stress. The rutin may reduce oxidative stress caused by ROS, such as hydrogen peroxide $\left(\mathrm{H}_{2} \mathrm{O}_{2}\right)$ (27). A possible preventive mechanism of rutin may be a scavenging effect on reactive oxygen radicals (ROS) (25). Rutin may protect cardiac tissue from oxidative damage due to the antiinflammatory effect associated with the inhibition of IL-1 $\beta$ and TNF- $\alpha$ (35). In another study, it has been noted that rutin prevents diabetic cardiac damage due to antioxidant and anti-inflammatory activity (36). Consistent with previous studies the inhibitory effect of rutin on antioxidant and cytokine is achieved at doses of $50 \mathrm{mg} / \mathrm{kg}$ (12).

In the present study, rutin significantly reduced the amount of cardiac TP I associated with immobi- 
lization stress damage. Stanely MPP and et. al showed the protective effect of rutin reducing both oxidative cardiac damage and the amount of TP I level induced by isoproterenol (37). In the RSG, we have found cardiac TP I level close to normal, as well as histopathologic changes such as myocardial damage, hemorrhage, edema, and PNL infiltration. Vasocongestion was significantly prevented. These structural changes are the morphological disorders seen in acute immobilization stress (5). These results are consistent with the previous study which has demonstrated the preventive effect of rutin on oxidative myocardial injury both biochemically and histopathologically (38).

As a conclusion, the immobilization method has been shown to lead oxidative stress and inflammatory reaction in the heart tissues and blood serum of rats. Furthermore, rutin demonstrated a preventive effect on acute stress-related oxidative cardiac damage induced by immobilization in rats both biochemically and histopathologically. These cardioprotective effects of the rutin are thought to be due to the antioxidant and anti-inflammatory activities. Our results have suggested that rutin might be useful for the protection against stress-related cardiac damage. In order to clarify the protective effect of the rutin against stress-related heart damage, the antistress and anxiolytic effects of the rutin should be investigated. Furthermore, functional studies might be carried out to confirm whether biochemical and histopathological changes correlate with cardiac function.

\section{Conflict of interest}

The authors declare no conflicts of interest.

\section{REFERENCES}

1. Celano C.M., Huffman J.C.: Cardiol. Rev. 19, 130 (2011).

2. Everson S.A., Kaplan G.A., Goldberg D.E., Salonen R., Salonen J.T.: Arterioscler. Thromb. Vasc. Biol. 17, 1490 (1997).

3. Weidner G., Spaderna H.: Emotions and Cardiovascular Disease, in Women and Health. Goldman M.B., Troisi R., Rexrode K.M.: 2 th Ed., pp. 991-1002, Academic Pres, San Diego 2013.

4. Rozanski A., Bairey C.N., Krantz D.S., Friedman J., Resser K.J. et al.: N. Engl. J. Med. 318, 1005 (1988).

5. Koptev M., Vynnyk N.: Wiad. Lek. 70, 767 (2017) (in Polish).
6. Salman S., Kumbasar S., Gursan N., Kumtepe Y., Borekci B. et al.: Int. J. Fertil. Steril. 5, 96 (2011).

7. Kunak C.S., Kukula O., Mutlu E., Genç F., Güleç Peker G. et al.: Oxid. Med. Cell. Longev. 2015, (2015).

8. de Souza F.G., Rodrigues M.D., Tufik S., Nobrega J.N., D’Almeida V.: Pharmacol. Biochem. Behav. 85, 400 (2006)

9. Kisaoglu A., Borekci B., Yapca O.E., Bilen H., Suleyman H.: Eurasian J. Med. 45, 47 (2013).

10. Urso M.L, Clarkson P.M.: Toxicology 189, 41 (2003).

11. Carden D.L., Granger D.N.: J. Pathol. 190, 255 (2000).

12. Taşlı N.G., Çimen F.K., Karakurt Y., Uçak T., Mammadov R. et al.: Int. J. Ophthalmol. 11, 780 (2018).

13. Mann D.L.: Annu Rev. Physiol. 65, 81 (2003).

14. Fuchs L.C., Landas S.K., Johnson A.K.: J. Hypertens. 15; 301 (1997).

15. Harborne J.B.: Prog. Clin. Biol. Res. 213, 15 (1986).

16. Ganeshpurkar A., Saluja A.K.: Saud. Pharm. J. 25, 149 (2017).

17. Lee W., Ku S.K., Bae J.S.: Food Chem. Toxicol. 50, 3048 (2012).

18. Bradford M.M.: Anal. Biochem. 72, 248 (1976).

19. Ohkawa H., Ohishi N., Yagi K.: Anal. Biochem. 95, 351 (1979).

20. Sedlak J., Lindsay R.H.: Anal. Biochem. 25, 192 (1968).

21. Bradley P.P., Priebat D.A., Christensen R.D., Rothstein G.: J. Invest. Dermatol. 78, 206 (1982).

22. Clarkson P.M., Thompson H.S.: Am. J. Clin. Nutr. 72, 637 (2000).

23. Cakir O.K., Ellek N., Salehin N., Hamamcý R., Keleş H. et al.: Physiol. Behav.168, 1 (2017).

24. Ozbeyli D., Gokalp A.G., Koral T., Ocal O.Y., Dogan B. et al.: Physiol. Behav. 151, 230 (2015).

25. Choi S.J., Lee S.N., Kim K., Joo D.H., Shin S. et al.: Int. J. Mol. Med. 38, 357 (2016).

26. Yapca O.E., Borekci B., Suleyman H.: Eurasian J. Med. 45, 126 (2013).

27. Singh S., Dubey V., Meena A., Siddiqui L., Maurya A.K., Luqman S.: Eur. J. Pharmacol. 835, 115 (2018).

28. Di Mascio P., Murphy M.E., Sies H.: Am. J. Clin. Nutr. 53, 194 (1991).

29. Zaidi S.K., Ansari S.A., Tabrez S., Hoda M.N., Ashraf G.M. et al.: Chin. J. Integr. Med. 1, 7 (2017). 
30. Samarghandian S., Azimi N.M., Farkhondeh T., Samini F.: Biomed. Pharmacother. 87, 223 (2017).

31. Shaker R.A., Abboud S.H., Assad H.C., Hadi N.: BMC Pharmacol. Toxicol. 19, 3 (2018).

32. Alpert J.S, Thygesen K., Antman E., Bassand J.: J. Am. Coll. Cardiol. 36, 959 (2000).

33. Coskun R., Turan M.I, Turan I.S., Gulapoglu M.: Drug Chem. Toxicol. 37, 290 (2014).

34. Hussein A., Ahmed A.A., Shouman S.A., Sharawy S.: Drug Discov. Ther. 6, 147 (2012).
35. Cail L., Kang Y.: Cardiovasc. Toxicol. 1, 181 (2001).

36. Saklani R., Gupta S.K., Mohanty I.R., Kumar B., Srivastava S., Mathur R.: Mol. Cell. Biochem. 420, 65 (2016).

37. Prince P.S.M., Priya S.: Eur. J. Pharmacol. 649, 229 (2010).

38. Ali M., Mudagal M., Goli D.: Pharmazie 64, 132 (2009).

Received: 15.07.2019 